Терещенко I. О., старший викладач

Полтавська державна аграрна академія

\title{
ФОРМУВАННЯ СТРАТЕГІЧНИХ НАПРЯМІВ ПІДВИЩЕННЯ КОНКУРЕНТОСПРОМОЖНОСТІ МОЛОЧНОГО СКОТАРСТВА
}

\section{Рецензент - кандидат економічних наук, доцент Л. В. Шульга}

Проведено комплексне дослідження інтенсивності впливу зовнішнього маркетингового середовища на формування стратегічних напрямів підвищення конкурентоспроможності продукиії молочного скотарства. Проаналізовано особливості розвитку молочного ринку Полтавської області та чотири типи сиенарію впливу PEST-факторів на виробників молока. Відповідно до тенденцій розвитку регіонального молочного ринку, позиції господарства та його иілей, сформовані стратегічні напрями підвищення конкурентоспроможності забезпечать стабільний розвиток молочного скотарства області.

Ключові слова: молочне скотарство, конкурентоспроможність, стратегічні напрями, маркетингове середовище, регіональний ринок.

Постановка проблеми. У зв'язку із затяжним перехідним періодом, реформами агропромислового сектора та низьким рівнем ефективності функціонування тваринницької галузі, обсяг виробництва сирого молока у 2012 р. (порівняно 3 1991 р.) зменшився у понад два рази, а рівень споживання молочних продуктів упав майже до критичного рівня.

У світі в цілому обсяг виробництва молока та молочних продуктів щороку зростає, якими вітчизняна продукція, у переважній більшості випадків, поступається позиціями у ціні та якості. Враховуючи той факт, що СОТ обмежує політику протекціонізму країн-учасників, продовольча незалежність України знаходиться наразі під загрозою. Саме тому постає гостра необхідність у формуванні стратегічних напрямів підвищення конкурентоспроможності вітчизняної продукції молочного скотарства.

Аналіз останніх досліджень і публікацій, у яких започатковано розв'язання проблеми. Проблемі низької конкурентоздатності продукції молочного скотарства присвячено чимало наукових праць вітчизняних вчених, у роботах яких висвітлені питання реформування тваринницької галузі, ефективного ціноутворення, стабілізації молочного ринку та підвищення прибутковості галузі. У різний час дослідженням цих питань займалися такі вчені як В.Я.Амбросов [2], М. В. Зубець, П. Т. Саблук, В. Я. МесельВеселяк [1], Ю. О. Лупенко [4]. Однак чимало аспектів, пов'язаних із підвищення конкурентоспроможності виробництва, залишаються недостатньо дослідженими, серед яких і формування стратегічних напрямів розвитку молочного скотарства.

Мета і завдання дослідження. Метою даного дослідження $\epsilon$ формування стратегічних напрямів підвищення конкурентоспроможності продукції молочного скотарства на основі положення господарства на регіональному ринку.

Передбачається також вирішення наступних завдань: аналіз сучасного стану та перспектив розвитку регіонального молочного ринку; визначення інтенсивності впливу факторів маркетингового зовнішнього середовища на розвиток молочного скотарства Полтавської області.

Матеріали та методи. У ході дослідження використовувалися загальнонаукові та спеціальні методи пізнання, зокрема: економічного аналізу (дослідження сучасних тенденцій розвитку молочного ринку); економіко-математичного прогнозування (в прогнозуванні тенденцій розвитку ринку); PEST-аналіз (в оцінці впливу факторів макросередовища). Статистичні та фінансово-економічні дані оброблялися за допомогою програмного забезпечення Microsoft Excel.

Результати дослідження. Для формування стратегічних напрямів підвищення конкурентоспроможності продукції молочного скотарства, виходячи 3 конкурентних положень господарств, необхідно проаналізувати й спрогнозувати привабливість регіонального молочного ринку, дослідити вплив факторів зовнішнього середовища.

Визначити привабливість молочного ринку Полтавської області можна за допомого теорії конкурентних переваг М. Портера [5], згідно 3 якою, привабливість регіонального ринку залежить від інтенсивності дії п'яти сил: загрози виникнення товарів-замінників, загрози появи нових конкурентів, суперництва між наявними виробниками, мірою залежності від постачальників 
та інтенсивності впливу покупців [5].

Оцінку інтенсивності дії кожної 3 п'яти сили проводили експертним методом, якщо сила: не має впливу на галузь, то інтенсивність дії становитиме 1 бал; має незначний вплив - 2 бали; має вагомий вплив - 3 бали; якщо ефективність виробництва в галузі залежить від впливу даної сили - 4 бали. Розглянемо загрозу появи товарівзамінників.

Основною продукцією молочного скотарства $є$ молоко - унікальний продовольчий продукт, який досі не синтезований, а компоненти молока майже повністю засвоюються організмом людини. Однак останнім часом, внаслідок розвитку наукового прогресу, у виробництві молочних продуктів стало можливим заміщення молочного жиру жиром рослинного погодження. Це дає змогу знизити собівартість продукції, а за умови низької купівельної спроможності населення й взагалі замінити молоко як сировину, хоча таке заміщення знижує якість продукції й негативно впливає на стан організму людини. Тому молоко власне не можна замінити товарами іншої групи, що гарантує стабільний попит із боку як кінцевих споживачів, так і переробників, хоча загроза заміщення молока як сировини досить висока. Оцінка ризику появи товару-субституту у молочній галузі становить 2 бали.

Наступний фактор - загроза появи нових конкурентів. Для дослідження цього фактора слід проаналізувати середньорічну кількість господарств. Із 2006 р. по 2010 р. кількість підприємств, що займалися виробництвом молока в області, зменшувалася в середньому на 11,0\% щорічно. Так, у 2006 р. їх кількість становила 365 од., а в 2010 р. на 45,2 \% менше - 200 одиниць [6].

За нашими прогнозами передбачалося, що чисельності підприємств молочного скотарства у 2011 р. становитиме 179 од., а у 2012 р. - 160 од., це на 56,1 \% менше від кількості 2006 року. Таким чином, оцінка загрози появи нових виробників молока у Полтавської області оцінена в 1 бал.

Конкуренцію у галузі молочного скотарства створюють середні та великі господарства. Щоб визначити інтенсивність впливу конкуренції (третьої сили) на привабливість галузі, необхідно визначити динаміку обсягу виробництва молока в області, в розрізі розмірів підприємств. Із 20062010 рр. питома вага дрібних підприємств зменшилася на 21,7 пункту, їх частка у валовому надої знизилася на 14,9 пункту. На 8,3 пунктів збільшилася кількість малих підприємств, частка у загальнообласному виробництві молока зменшилась на 8,3 пункту. Середніх підприємств у 2010 р. стало на 6,7 пункти білыше, ніж у 2006 р.; великих - на 3,2 пункту, а надвеликих - на 3,5 пункту. Підвищилася також їх частка у валовому удої - на 3,6, 6,0, та 13,6 пунктів відповідно [6].

Зважаючи на той, факт, що на період дослідження була відсутня статистична інформація про стан молочної галузі у 2011 році, прогноз їі розвитку ми зробили на період 3 20112012 років. Згідно якого, за прогнозний період, спостерігатиметься поступове зниження частки дрібних підприємств (i3 52,6 \% до 47,2 \%). До того ж воловий надій групи зменшиться $311,7 \%$ до $8,0 \%$. Частка малих підприємств підвищиться з 24,6 \% - у 2011 р. до $26,7 \%$ - у 2012 р., хоча їх частка у валовому надої сільськогосподарських підприємств області знизиться $3 \quad 23,0 \%$ до $21,0 \%$. Питома вага груп середніх, великих i надвеликих підприємств, збільшиться 3 12,2 \%, 4,8 \%, та 5,9\%, до $13,9 \%, 5,6 \%$, та 6,8 \% відповідно. Обсяг виробленого молока групою середніх господарств збільшиться з 21,9\% - у 2011 р. до $22,8 \%$; великих - із $13,1 \%$ до $14,6 \%$. Найбільше зростання частки у питомій вазі валового надою прогнозується у групі надвеликих господарств, - iз 30,3 \% у перший прогнозний рік, і до $33,7 \%$ - у другому. Отже, рівень конкуренції між виробниками має суттєвий вплив на розвиток молочного скотарства регіону, а оцінка інтенсивності становитиме 3 бали.

Наступний фактор - залежність від постачальників - чинить незначний вплив, оскільки підприємства, що займаються молочним скотарством, мають у своєму розпорядженні всі ресурси для забезпечення тварин достатньою кількістю кормів - як грубими й соковитими, так і концентрованими. Виробники молока співпрацюють із постачальниками досить рідко, придбаючи ветеринарні засоби, устаткування й обладнання тощо. Зважаючи на те, що на обласному ринку функціонує значна кількість продавців, рівень впливу спостерігатиметься мінімальний - 1 бал.

Останній досліджуваний фактор - це сила впливу покупців. Основними покупцями молока у сільськогосподарських господарствах $є$ переробні підприємства. Зважаючи на той факт, що якісні характеристики молока, його клас, а отже й ціну, визначають переробні підприємства, сили їх впливу оцінена в 3 бали.

У таблиці 1 підсумуємо результати аналізу сучасного стану та перспектив розвитку регіонального молочного ринку, і в залежності від величини сумарної ваги впливу п'яти сил конкуренції визначимо привабливість галузі молочного скотарства Полтавської області. 
1. Розрахунок впливу п'яти сил конкуренції (за Портером) на привабливість галузі молочного скотарства Полтавської області

\begin{tabular}{|c|c|c|c|c|c|}
\hline \multirow{2}{*}{ Показник } & \multicolumn{5}{|c|}{ П’ять сил впливу } \\
\cline { 2 - 6 } & $\begin{array}{c}\text { загроза появи } \\
\text { товару- } \\
\text { замінника }\end{array}$ & $\begin{array}{c}\text { загроза появи } \\
\text { нових } \\
\text { конкурентів }\end{array}$ & $\begin{array}{c}\text { рівень кон- } \\
\text { куренції } \\
\text { на ринку }\end{array}$ & $\begin{array}{c}\text { вагомість } \\
\text { впливу } \\
\text { покупців }\end{array}$ & $\begin{array}{c}\text { вагомість } \\
\text { впливу поста- } \\
\text { чальників }\end{array}$ \\
\hline $\begin{array}{c}\text { Коефіціснт питомої ваги } \\
\text { сили }\end{array}$ & 0,2 & 0,2 & 0,2 & 0,2 & 0,2 \\
\hline Оцінка показника & 2 & 1 & 3 & 3 & 1 \\
\hline Відносна оцінка показника & 0,4 & 0,2 & 0,6 & 0,6 & 0,2 \\
\hline Сумарна вага впливу & \multicolumn{5}{|c|}{2} \\
\hline
\end{tabular}

Джерело: розраховано на основі [5]

3 даних таблиці 1 бачимо, що сумарна вага впливу п'яти сил конкуренції становить 2 бали. Це свідчить про високу інвестиційну привабливість регіонального ринку молочного скотарства.

Вагомий вплив на формування стратегічних напрямів підвищення конкурентоспроможності мають також фактори маркетингового макросередовища. Їх сукупність чинить визначальну дію, оскільки підприємство не має впливу і повинно адаптуватися до них [3, с. 70]. Проаналізувати сучасний та прогнозні сценарії розвитку макросередовища можна за допомогою оцінки чотирьох типів сценаріїв впливу PEST-факторів (табл. 2).

Змодельований реалістичний прогнозний сценарій свідчить, що PEST-фактори мають суттєвий вплив на формування стратегічних напрямів підвищення конкурентоспроможності молочного скотарства Полтавської області. Ефективність виробництва залежатиме від групи економічних факторів, зокрема від ціни реалізації сирого молока й молочних продуктів та соціальнодемографічних, у тому числі потреб й уподобань споживачів.

\section{2. Прогнозна оцінка впливу PEST-факторів на розвиток молочної галузі Полтавської області}

\begin{tabular}{|c|c|c|c|c|c|c|c|c|c|c|c|c|}
\hline \multirow{4}{*}{$\begin{array}{c}\text { Фактори маркетингового } \\
\text { середовища }\end{array}$} & \multirow{2}{*}{\multicolumn{3}{|c|}{ 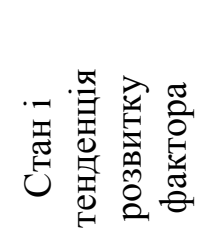 }} & \multirow{4}{*}{ 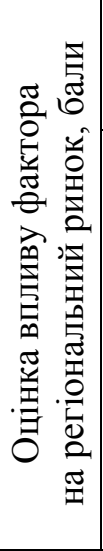 } & \multicolumn{3}{|c|}{$\begin{array}{l}\text { Реальний } \\
\text { сценарій }\end{array}$} & \multicolumn{2}{|c|}{$\begin{array}{l}\text { Оптимістич- } \\
\text { ний прогноз- } \\
\text { ний сценарій }\end{array}$} & \multicolumn{2}{|c|}{$\begin{array}{l}\text { Песимістич- } \\
\text { ний прогноз- } \\
\text { ний сценарій } \\
\end{array}$} & \multirow{4}{*}{$\begin{array}{l} \\
\end{array}$} \\
\hline & & & & & 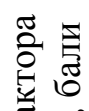 & $>1$ & 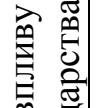 & : & 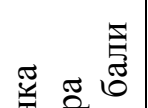 & 寻 & 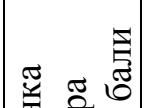 & \\
\hline & \multicolumn{3}{|c|}{ роки } & & 魚兽 & $\sum_{\Sigma}^{\infty}$ है & $\begin{array}{lll}5 & 0 \\
5 & 0\end{array}$ & $\stackrel{2}{2}$ & 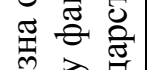 & $\stackrel{2}{2}$ & 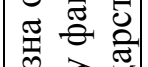 & \\
\hline & $\stackrel{\infty}{\stackrel{\infty}{2}}$ & ஓें & $\frac{0}{\stackrel{1}{0}}$ & & 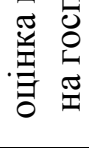 & 预 & 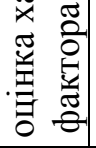 & 言 & 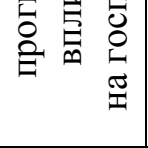 & 産 & 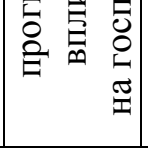 & \\
\hline \multicolumn{13}{|c|}{ 1. Політико-правові фактори } \\
\hline $\begin{array}{l}\text { 1.1. Неузгодженості вико- } \\
\text { навчої і законодавчої бази }\end{array}$ & - & - & + & 2 & 1 & - & -2 & 0,8 & 2 & 0,2 & -1 & 2,8 \\
\hline $\begin{array}{c}\text { 1.2. Регульованість } \\
\text { виробничих відносин }\end{array}$ & - & + & + & 2 & 2 & - & -4 & 0,6 & 2 & 0,4 & -2 & 0,8 \\
\hline $\begin{array}{c}\text { 1.3. Впровадження } \\
\text { економічних реформ }\end{array}$ & - & - & + & 3 & 2 & + & 6 & 0,6 & 2 & 0,4 & -1 & 2,4 \\
\hline $\begin{array}{c}\text { 1.4. Сертифікація і } \\
\text { стандартизація товарів }\end{array}$ & + & - & + & 2 & 3 & + & 6 & 0,6 & 2 & 0,4 & -1 & 1,6 \\
\hline $\begin{array}{l}\text { 1.5. Діяльність антимоно- } \\
\text { польного комітету }\end{array}$ & + & + & - & 1 & 2 & + & 2 & 0,4 & 1 & 0,7 & -2 & -1 \\
\hline \multicolumn{7}{|c|}{ Разом політико-правові фактори: } & 8 & & & & & 6,6 \\
\hline
\end{tabular}


Продовження табл. 2

\begin{tabular}{|c|c|c|c|c|c|c|c|c|c|c|c|c|}
\hline \multicolumn{13}{|c|}{ 2. Економічні фактори } \\
\hline $\begin{array}{l}\text { 2.1. Підвищення попиту на } \\
\text { молочні продукти в області }\end{array}$ & + & + & + & 3 & 2 & + & 6 & 0,9 & 3 & 0,1 & -2 & 7,5 \\
\hline $\begin{array}{l}\text { 2.2. Підвищення ціни на } \\
\text { молочні продукти в області }\end{array}$ & + & + & - & 2 & 1 & - & -2 & 0,4 & 1 & 0,6 & -3 & $-2,8$ \\
\hline 2.3. Інфляційні процеси & + & - & - & 2 & 1 & - & -2 & 0,4 & 1 & 0,6 & -2 & $-1,6$ \\
\hline 2.4. Державна підтримка & + & + & - & 2 & 3 & + & 6 & 0,4 & 2 & 0,6 & -2 & $-0,8$ \\
\hline $\begin{array}{l}\text { 2.5. Рівень зареєстрованого } \\
\text { безробіття в області }\end{array}$ & + & - & + & 2 & 1 & - & -2 & 0,7 & 1 & 0,3 & -1 & 0,8 \\
\hline 2.6. Податкова політика & + & + & - & 1 & 2 & - & -2 & 0,6 & 2 & 0,4 & -1 & 0,8 \\
\hline $\begin{array}{l}\text { 2.7. Життєвий рівень } \\
\text { населення }\end{array}$ & + & - & - & 3 & 2 & + & 6 & 0,6 & 3 & 0,4 & -1 & 4,2 \\
\hline Разом економічні фактори: & & & & & & & 10 & & & & & 8,1 \\
\hline \multicolumn{13}{|c|}{ 3. Соціально-демографічні фактори } \\
\hline 3.1. Чисельність населення & + & - & - & 3 & 2 & + & 6 & 0,3 & 2 & 0,7 & -1 & $-0,3$ \\
\hline $\begin{array}{l}\text { 3.2. Частка літніх людей } \\
\text { та дітей }\end{array}$ & - & + & + & 3 & 1 & + & 3 & 0,9 & 3 & 0,1 & -1 & 7,8 \\
\hline 3.3. Рівень народжуваності & - & - & + & 2 & 1 & + & 2 & 0,8 & 3 & 0,2 & -2 & 4 \\
\hline 3.4. Рівень смертності & - & - & - & 2 & 2 & - & -4 & 0,2 & 2 & 0,8 & -1 & $-0,8$ \\
\hline 3.5. Культурний рівень & - & - & + & 1 & 1 & + & 1 & 0,7 & 2 & 0,3 & -1 & 1,1 \\
\hline \multicolumn{7}{|c|}{ Разом соціально-демографічні фактори: } & 8 & & & & & 11,8 \\
\hline \multicolumn{13}{|c|}{ 4. Техніко-технологічні фактори } \\
\hline $\begin{array}{l}\text { 4.1. Фінансування } \\
\text { наукоємних галузей }\end{array}$ & + & - & - & 1 & 1 & + & 1 & 0,6 & 2 & 0,4 & -1 & 0,8 \\
\hline $\begin{array}{c}\text { 4.2. Впровадження } \\
\text { передових технологій }\end{array}$ & - & + & + & 1 & 3 & + & 3 & 0,9 & 3 & 0,1 & -1 & 2,6 \\
\hline $\begin{array}{l}\text { 4.3. Науково-технічний } \\
\text { потенціал області }\end{array}$ & + & + & + & 1 & 1 & + & 1 & 0,6 & 1 & 0,4 & -1 & 0,2 \\
\hline \multicolumn{7}{|c|}{ Разом техніко-технологічні фактори: } & 5 & & & & & 3,6 \\
\hline
\end{tabular}

Джерело: опрацьовано на основі [3]

\begin{tabular}{|c|c|c|c|c|c|c|c|c|c|c|}
\hline \multirow{2}{*}{$\begin{array}{c}\text { Темп зміни } \\
\text { конкурентних переваг }\end{array}$} & & \multicolumn{8}{|c|}{ Конкурентна позиція господарства на ринку } & \multirow{3}{*}{$\begin{array}{c}\text { Стратегічні } \\
\text { напрями } \\
\text { підвищення ефек- } \\
\text { тивності реалізаціі } \\
\text { конкурентних } \\
\text { переваг }\end{array}$} \\
\hline & & \multicolumn{2}{|c|}{ лідера (А) } & \multicolumn{2}{|c|}{ сильна (Б) } & \multicolumn{2}{|c|}{ слабка ( В) } & \multicolumn{2}{|c|}{ аутсайдера (Г) } & \\
\hline $\begin{array}{c}\text { Високий темп підви- } \\
\text { щення конкурентних } \\
\text { переваг (1) }\end{array}$ & & \multirow{4}{*}{ 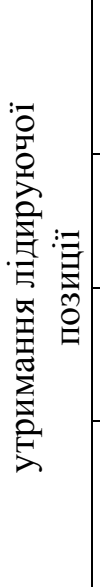 } & A1 & \multirow{4}{*}{ 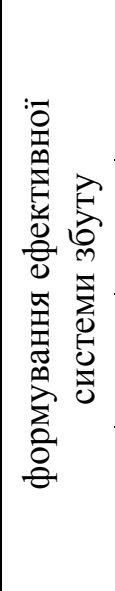 } & Б1 & \multirow{4}{*}{ 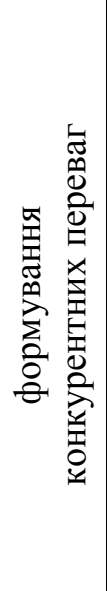 } & B1 & \multirow{4}{*}{ 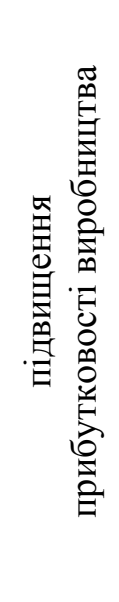 } & $\Gamma 1$ & \\
\hline $\begin{array}{r}\text { Низький } \\
\text { щення кс } \\
\text { пер }\end{array}$ & & & A2 & & Б2 & & B2 & & $\Gamma 2$ & $\begin{array}{c}\text { диверсифікація } \\
\text { виробництва й } \\
\text { каналів збуту }\end{array}$ \\
\hline $\begin{array}{c}\text { Низький темп знижен- } \\
\text { ня конкурентних } \\
\text { переваг (3) }\end{array}$ & & & A3 & & Б3 & & B3 & & $\Gamma 3$ & $\begin{array}{c}\text { підвищення темпу } \\
\text { нарощення конку- } \\
\text { рентних переваг }\end{array}$ \\
\hline $\begin{array}{c}\text { исокий темп знижен- } \\
\text { ня конкурентних } \\
\text { переваг (4) }\end{array}$ & & & A4 & & Б4 & & B4 & & $\Gamma 4$ & $\begin{array}{c}\text { техніко- } \\
\text { технологічна } \\
\text { модернізація } \\
\text { виробництва }\end{array}$ \\
\hline
\end{tabular}

Рис. Матриця формування стратегічних напрямів підвищення конкурентоспроможності вітчизняного молочного скотарства

Джерело: власна розробка 
Стратегічні напрями підвищення конкурентоспроможності молочного скотарства повинні відповідати встановленим цілям господарства, які, у свою чергу, залежать від його положення на ринку, напряму й темпу зміни конкурентних переваг. Виходячи 3 цього, існує шістнадцять можливих варіантів встановлення стратегічних цілей та формування стратегічних напрямів підвищення конкурентоспроможності молочної галузі (див. рис.).

Iз даних рисунка бачимо, що основними стратегічними напрямами підвищення конкурентоспроможності молочного скотарства у господарствах Полтавської області є:

- підвищення ефективності реалізації наявних конкурентних переваг (підприємства, які швидко нарощують конкурентні переваги);

- диверсифікація виробництва, каналів збуту готової продукції та сировини (підприємства, які повільно нарощують конкурентні переваги);

- підвищення нарощення темпу й кількості конкурентних переваг (підприємства, які повільно втрачають конкурентні переваги);

- техніко-технологічна модернізація виробни-

\section{БІБЛІОГРАФІЯ}

1. Аграрний сектор економіки України (стан i перспективи розвитку) / [Присяжнюк М. В., Зубець М. В., Саблук П. Т. та ін.] ; за ред. М. В. Присяжнюка, М. В. Зубця, П. Т. Саблука, В. Я. МесельВеселяка, М. М. Федерова. - К. : ННЦ ІАЕ, 2011. - $1008 \mathrm{c}$.

2. Амбросов В. Я. Оцінка конкурентоспроможності агроформувань / В. Я. Амбросов, Т. Г. Маренич // Вісник ХНАУ. Серія : Економіка АПК і природокористування. - 2009. - № 10. - С. 23-28.

3. Балабанова Л. В. Стратегічне маркетингове управління конкурентоспроможністю підприємств : [навч. посіб.] / Л. В. Балабанова, В. В. Холод. - К. : цтва (підприємства, які швидко втрачають конкурентні переваги).

Стратегічні напрями розвитку молочного скотарства можуть бути використані й в іншому порядку, поскільки конкурентна позиція й темп нарощення переваг - це відносні показники, які визначають спроможність підприємства організувати ефективне виробництво порівняно 3 iншими суб' єктами.

Висновки. Аналіз інтенсивності дії п'яти сил конкуренції та прогноз оцінки впливу PESTфакторів на розвиток молочного сектора Полтавської області свідчать, що молочне скотарство $\epsilon$ інвестиційно привабливою галуззю, а ефективність іiї виробництва залежатиме від ціни реалізації сирого молока і молочних продуктів, а також потреб й уподобань споживачів. Відповідно до тенденцій розвитку регіонального молочного ринку, позиції господарства та його цілей, сформовані стратегічні напрями підвищення конкурентоспроможності забезпечать стабільний розвиток молочного скотарства й підвищать конкурентоспроможність вітчизняної молочної продукції на міжнародному рівні.

Професіонал, 2006. -448 с.

4. Лупенко Ю. О. Стратегічні напрями розвитку сільського господарства України на період до 2020 року / За ред. Ю. О. Лупенка, В. Я. МесельВеселяка. - К. : ННЦ ІАЕ, 2012. -182 с.

5. Портер М. Конкуренция. : [учебн. пособие, пер. с англ.] / М. Портер. - М. : Издательский дом «Вильямс», 2001. $-495 \mathrm{c}$.

6. Сільське господарство області у 2010 році : [статистичний збірник]. - Полтава: Головне управління статистики у Полтавській області, 2011. -269 c. 